Artigo / Article

\title{
CLL: Chromosomal abnormalities (FISH) and their relation with clinical stage, CD38 and ZAP-70
}

\author{
Leucemia linfocítica crônica: Anormalidades cromossômicas e a sua relação com o estágio clínico \\ CD38 e о ZAP-70
}

\author{
Marilia C. Nascimento \\ Mioko Yamamoto \\ Maria Madalena Rodrigues \\ Luciana F. Franco \\ Elisa Y. S. Kimura \\ Yuri Vasconcelos \\ José S. R. Oliveira \\ Vera L. P. Figueiredo \\ Maria de Lourdes L. F. Chauffaille
}

\begin{abstract}
Chronic lymphocytic leukemia is the most prevalent type of leukemia in the West. It is characterized by an extremely variable clinical course. The aim of the study was to detect the most frequent chromosomal abnormalities in patients with CLL using FISH, and assess them regarding age, gender, clinical stage and CD38 and ZAP-70 expressions. We found $51.7 \%$ of the patients with chromosome abnormalities. The most frequent one was del $13 q 14$ in $34.5 \%$ of cases. It was associated to other alterations in $17.2 \% .17 p 13$ deletions were found in $17.2 \%$ and trisomy 12 in $13.8 \%$ (in isolation in $6.9 \%$ and associated to del 13q14, in 6.9\% of the cases). An 11q22 deletion was found in one case associated to a $13 q 14$ deletion. To better evaluate the relationship between chromosome aberrations and other prognostic factors in CLL, two cytogenetics groups were considered: favorable (13q deletion in isolation and no alteration) and unfavorable outcomes (trisomy 12, 17p13 deletion, 11q22 deletion and two simultaneous alterations).The unfavorable alterations were more frequently seen among young individuals ( $<60 y)$. There were more females $(70 \%)$ than males in this group $(p=0.04)$. In relation to the Binet's staging system, patients with unfavorable cytogenetic alterations, tended to be $B$ and $C$ stages, while in the favorable group prevailed patients in stage A. Additionally, patients with poor prognostic cytogenetics tended to express CD38 and ZAP-70 proteins. Rev. bras. hematol. hemoter. 2006; 28(1):5-10.
\end{abstract}

Key words: Chronic lymphocytic leukemia; FISH; cytogenetics.

\section{Introduction}

Chronic lymphocytic leukemia is the most prevalent type of leukemia in the West. ${ }^{1}$ Approximately $65 \%$ of the cases are diagnosed in an asymptomatic phase and around $70 \%$ to $80 \%$ of the patients present low tumor masses. ${ }^{2}$

The disease is characterized by an extremely variable clinical course, while some patients have an indolent course and never require treatment, others present a quickly progressive evolution and prompt treatment is required. ${ }^{3,5}$
The classical staging systems of the disease, Rai ${ }^{6}$ and Binet's, ${ }^{7}$ are based on clinical and hematological features. However in CLL early stages, neither system accurately distinguishes patients who may rapidly transform into aggressive disease from those who will remain with indolent disease. Since the introduction of staging systems, there has been a continuous effort to identify new prognostic factors for CLL. Recently, new markers of prognostic impact have been investigated and associated to poor prognosis including unmutated $V_{H}$ genes (immunoglobulin heavy-chain variable

${ }^{1}$ Disciplina de Hematologia e Hemoterapia, Universidade Federal de São Paulo, Escola Paulista de Medicina, Brazil.

${ }^{2}$ Hospital Servidor Público do Estado de São Paulo, Brazil.

Correspondence: Maria de Lourdes L.F. Chauffaille

Disciplina de Hematologia e Hemoterapia - Universidade Federal de São Paulo-EPM

Rua Botucatu $740,3^{\circ}$ andar, Vila Clementino

04023-900 - São Paulo-SP, Brazil

Tel: +(55 11) 55764240 Fax: +(55 11) 55718806

E-mail: chauffaill@hemato.epm.br 
genes) status, high expression of CD38 on the surface of the leukemic cells and high expression of the ZAP-70 gene. -14 $^{8-14}$

Cytogenetic alterations have also been related with prognosis in CLL. ${ }^{4,5,15}$ In that sense, there is a great interest in identifying chromosome alterations that can define subgroups of patients with different prognosis.

The most important numerical and structural abnormalities found in CLL include trisomy 12 and deletions in several chromosome regions, such as 13q14, 11q, and $17 \mathrm{p} 13$, as well as other less frequently occurring aberrations. ${ }^{16}$

Trisomy 12 is identified as the most common numeric chromosome abnormality, being frequently associated with atypical lymphocyte morphology, advanced disease and an aggressive clinical course. ${ }^{17,18}$

Structural abnormalities more frequently involve the long arm of chromosome 13 with different breakpoints, including deletions of 13q14. Deletions or translocations of the 13q14 have been associated with typical morphology CLL and do not carry an adverse prognostic significance. ${ }^{17,19}$

A 11q deletion has been associated with rapidly progressive disease, extensive lymphadenopathy, advanced stages, shorter treatment-free intervals and shorter survival times. ${ }^{16}$ Allelic loss of chromosome 17p, the site of the p53 gene, is often associated with poor clinical outcome and drug resistance..$^{20,21}$

More than half of the abnormal karyotypes are constituted by single abnormalities, whereas complex karyotypes are found in $10 \%$ to $15 \%$ of all patients. ${ }^{15}$

Any clonal chromosomal abnormality indicates a poorer prognosis compared to a normal karyotype. However, the complexity of the karyotype is a significant parameter. Single abnormalities indicate a longer survival than multiple abnormalities. $^{22}$

\section{Objective}

The aim of our investigation was to detect the most frequent chromosome anomalies in a group of 29 patients with CLL by fluorescence in situ hybridization (FISH), using probes specific for the chromosome 12 centromere, 13q14.3 (D13S319), 17p13.1 (p53) and 11q22 (ATM), and to relate the results to age, gender, clinical stage, CD38 and ZAP-70 expression.

\section{Materials and Methods}

Peripheral blood samples were collected from 29 patients with CLL from Universidade Federal de São Paulo and Hospital Servidor Público Estadual between 2002 and 2004. The diagnosis was based on morphology and immunophenotype. This study was approved by the local Ethics Committee.

The expression of CD38 was studied on leukemic cells using flow cytometer (FACS calibur, Becton Dickinson, San
Jose) and performed together with the diagnostic immunophenotypic analysis. The CD38 monoclonal antibody conjugated with phycoerythrin (PE, BD) was used. Positivity was considered when $30 \%$ or more cells expressed the antigen. ${ }^{8}$

The expression of the ZAP-70 protein was determined in cryopreserved leukemic cells, using the anti-ZAP-70 (UPSTATE) monoclonal antibody and the anti mouse IgG antibody conjugated with fluorescein isothiocyanate (DAKO), as the second antibody. Acquisition and analysis were done by flow cytometry (FACS calibur, BD) using the software CellQuest (BD). Values above $20 \%$ were considered positive. ${ }^{14}$

FISH was performed using probes specific for the chromosome 12 centromere, 13q14.3 (D13S319), 17p13.1 (p53) and 11q22 (ATM) (Vysis). Slides were prepared from material fixed in methanol-acetic acid.

All four probes were set up separately on different slides for each patient. Hybridization and detection of hybridization signals were performed according to the manufacturer's protocols. At least two technologists scored the same case. For each probe, at least 100 nuclei were evaluated. Images of FISH were captured through the program MacProbe 4.4 of PowerGene System (Applied Imaging Corporation, USA).

Peripheral blood samples from healthy individuals were used as a control. Means and standard deviations (SD) of the percentage of nuclei with hybridization signals were calculated. Results were considered abnormal if the percent of nuclei with the abnormal hybridization signal was $>2$ SD from the mean.

Fisher's exact test was used to test whether there was significant relation between FISH characteristics and age, gender, Binet stage, CD38 and ZAP-70 expression. Statistical significance was accepted at $5 \%(\alpha=0.05)$.

\section{Results}

Fifteen patients (51.7\%) presented chromosomal abnormalities: 10 (34.5\%) with a single aberration and five (17.2\%) with two anomalies. The remaining 14 cases (48.3\%), had no cytogenetic abnormality identified (Table 1).

The most frequently observed aberration was 13q14 deletions observed in 10 patients (34.5\% of the total of cases and $66.6 \%$ of the abnormalities), in isolation in five cases (17.2\%) and associated to other anomalies in the other five (trisomy 12, del 11q22 and del 17p13). 17p13 deletions were found in five patients (17.2\%), in isolation in three and associated to del 13q14 in two, as already mentioned. Trisomy 12 was isolated in two patients (6.9\%), and associated to deletion 13q14, in two (13.8\% of the total cases and $26.7 \%$ of the alterations).

A 11q22 deletion was found in one case associated to a 13q14 deletion (6.7\% of the abnormalities) (Table 1). 
Table 1

Frequency of cytogenetics abnormalities detected by FISH in 29 patients with CLL

\begin{tabular}{lrcc}
\hline Abnormality & $\mathrm{n}$ & $\begin{array}{c}\% \text { total } \\
\text { of patients }\end{array}$ & $\begin{array}{c}\% \\
\text { of abnormalities* }\end{array}$ \\
\hline Abnormality & 15 & 52 & \\
No abnormality & 14 & 48 & 13,3 \\
Trisomy 12 & 2 & $6,9 \psi$ & 0 \\
Deletion 11q22 & 0 & $0 \psi$ & 20 \\
Deletion 17q13 & 3 & $10,3 \psi$ & 33,3 \\
Deletion 13q14 & 5 & $17,2 \psi$ & 13,3 \\
del 13q14 + trisomy 12 & 2 & $6,9^{*}$ & 6,7 \\
del 13q14 + 11q22 & 1 & $3,5^{*}$ & 13,3 \\
del 13q14+ 17q13 & 2 & $6,9^{*}$ & 100 \\
total & 29 & 100 & \\
\hline
\end{tabular}

Obs: $\psi$ total $=34,4 \% ;{ }^{*}$ total $=17,3 \% ; \mathrm{n}=15$

Table 2

Frequency of cytogenetics abnormality detected by FISH in 29 patients with CLL in relation with age, gender and Binet clinical stage, CD38 and ZAP-70 expression

\begin{tabular}{|c|c|c|c|c|c|c|}
\hline & normal & trisomy 12 & del 11q22 & del 17q13 & del 13q14.3 & $\begin{array}{c}2 \text { simultaneous } \\
\text { abnormalities }\end{array}$ \\
\hline \multicolumn{7}{|l|}{ Age } \\
\hline$<60$ & 3 & 0 & 0 & 2 & 0 & 2 \\
\hline$>60$ & 11 & 2 & 0 & 1 & 5 & 3 \\
\hline \multicolumn{7}{|l|}{ Gender } \\
\hline M & 9 & 1 & 0 & 2 & 5 & 0 \\
\hline $\mathrm{F}$ & 5 & 1 & 0 & 1 & 0 & 5 \\
\hline \multicolumn{7}{|l|}{ Binet stage } \\
\hline A & 9 & 1 & 0 & 1 & 2 & 2 \\
\hline B & 1 & 0 & 0 & 2 & 3 & 2 \\
\hline C & 4 & 1 & 0 & 0 & 0 & 1 \\
\hline \multicolumn{7}{|l|}{ CD 38} \\
\hline Positive & 4 & 0 & 0 & 3 & 0 & 3 \\
\hline Negative & 10 & 2 & 0 & 0 & 5 & 2 \\
\hline \multicolumn{7}{|l|}{ ZAP-70* } \\
\hline Positive & 6 & 2 & 0 & 3 & 1 & 1 \\
\hline Negative & 7 & 0 & 0 & 0 & 4 & 4 \\
\hline Total (n) & 14 & 2 & 0 & 3 & 5 & 5 \\
\hline$\%$ & 48,3 & 6,9 & 0 & 10,3 & 17,2 & 17,2 \\
\hline
\end{tabular}

Table 2 demonstrates the frequencies of the cytogenetics alterations studied in relation to age, gender, Binet stage, CD38 and ZAP-70 expressions.

To better study the relationship between chromosome aberrations and other prognostic factors in CLL, we separated the patients in two cytogenetic groups: favorable (isolated $13 q$ deletion and no alterations) and unfavorable outcomes (trisomy 12, 17p13 deletion, 11q22 deletion and two simultaneous alterations) (Table 3).

We found that in relation to patients' age, the unfavorable alterations were more frequently observed among young individuals ( $57 \%$ of the $<60$ years) while these alterations were found in only $27.2 \%$ of elderly patients (above 60 years). Favorable alterations were seen more frequently among elderly patients. However, this difference was not statistically significant.

In relation to gender, there was a prevalence of females (70\%) in the worse prognostic group and prevalence of males in the group with a better prognosis $(73 \%)(p=0.04)$.

In relation to the Binet's staging system, the patients with cytogenetic alterations of worse prognosis, tended to be B and C stages (6/10 $60 \%$ ), while in the favorable group stage A patients prevailed (11/19 - 57.8\%).

All patients were evaluated for CD38 expression, with 10 positive cases ( $\geq=30 \%$ ) for this antigen. Patients with poor prognostic cytogenetics tended to present with positive CD38 expression in comparison to the others $(p=0.051)$.

The ZAP-70 expression was investigated in 28 cases and found positive in 13 patients. In the group of unfavorable cytogenetics, six patients (60\%) were positive for ZAP-70 while in the favorable group, there was a prevalence (58\%) of ZAP-70 negative individuals.

\section{Discussion}

CLL is characterized by a highly variable clinical course: while some patients present quick progressive evolutions, others have an indolent course with more than 30 years of survival. ${ }^{22}$

At the time of diagnosis, it is often difficult to distinguish patients who are likely to remain stable from those who will progress and require treatment. Prognostic factors have traditionally relied on disease stage, based primarily on tumor bulk. A number of new prognostic factors have recently been proposed to better identify patients at increased risk. These new directions are based on cytogenetic alterations, as well as molecular and immunophenotypic studies. ${ }^{23}$

Published data reveal that chromosomal alterations are detected in only 30 to $40 \%$ of the cases by conventional cytogenetics, while these indexes reach up to $82 \%$ when molecular cytogenetics (FISH) is used. ${ }^{4}$ In this study we found chromosome alterations in $52 \%$ of the patients with the 4 probes used.

Trisomy 12 is found, varying from 11.5 to $37 \%$ in published series. ${ }^{24,25}$ In this study $13.8 \%$ of the patients had trisomy 12 , half of which were associated to $13 q 14$ deletion.

Hjalmar et al (2001) ${ }^{18}$ studying sequential FISH for the chromosome 12 , demonstrated that the percentage of cells with trisomy 12 increased during the follow-up period in patients with signs of progressive disease requiring therapy. They also demonstrated that the relative size of the 
Table 3

Comparison of unfavorable v. favorable cytogenetics alterations detected by FISH in patients with CLL in relation to age, gender, Binet clinical stage, CD 38 and ZAP-70 expression

\begin{tabular}{|c|c|c|c|c|}
\hline & & Unfavorable & Favorable & \\
\hline & & $\begin{array}{c}\text { Trisomy } 12, \text { del } 17 p 13, \text { del } 11 q 22 \text { e } \\
2 \text { simultaneous alterations }\end{array}$ & $\begin{array}{c}\text { No cytogenetic alteration and del } \\
13 q 14\end{array}$ & \\
\hline & $(\mathrm{N})$ & $(\mathrm{N}=10) \mathrm{n}(\%)$ & $(\mathrm{N}=19) \mathrm{n}(\%)$ & $p^{*}$ \\
\hline \multicolumn{5}{|l|}{ Age } \\
\hline$>60$ & 22 & $6(27,3 \%)$ & $16(72,7 \%)$ & \\
\hline$<60$ & 7 & $4(57 \%)$ & $3(43 \%)$ & $F=0,19$ \\
\hline \multicolumn{5}{|l|}{ Gender } \\
\hline$M$ & 17 & $3(30 \%)$ & $14(74 \%)$ & \\
\hline $\mathrm{F}$ & 12 & $7(70 \%)$ & $5(26 \%)$ & $F=0,04$ \\
\hline \multicolumn{5}{|l|}{ Binet } \\
\hline$A$ & 15 & $4(40 \%)$ & $11(58 \%)$ & \\
\hline$B+C$ & 14 & $6(60 \%$ & $8(42 \%)$ & $F=0,44$ \\
\hline CD38 + & 10 & $6(60 \%)$ & $4(21 \%)$ & \\
\hline CD28 - & & $4(40 \%)$ & $15(78 \%)$ & $F=0,051$ \\
\hline ZAP $70+$ & 13 & $6(60 \%)$ & 7 (39\%) & \\
\hline ZAP 70 - & 15 & $4(40 \%)$ & $11(61 \%)$ & $F=0,43$ \\
\hline
\end{tabular}

to the retinoblastoma (RB1) gene is often deleted in CLL and is thought to have a tumor suppressor function. Structural abnormalities of chromosome 13 have been associated with early clinical stage, typical morphology and as good prognosis as cases with normal karyotypes. ${ }^{23,32}$

To better assess the chromosomes aberrations regarding other prognostic factors in CLL, we separated the patients in two cytogenetic groups: favorable $(13 q$ deletion in isolation and no alteration) and unfavorable outcome (trisomy 12, 17p13 deletion, 11q22 deletion and two simultaneous alterations).

We found that in relation to patients' age, the unfavorable alterations were more frequent among the young (57\% of the $<60$

trisomic clone decreases significantly after successful chemotherapy. However, the acquisition of an extra chromosome 12 in CLL has so far been reported only in patients with signs of transformation to Richter's syndrome. The patients with trisomy 12 in this study also presented CD38 and/or ZAP-70+ indicating an unfavorable disease course which was afterwards confirmed.

Using specific locus probe for the chromosome 11q22 (ATM locus) we found a deletion in only one (3.4\%) patient out of 29, and that alteration was associated to the $13 q 14$ deletion. 11q22 deletion incidence in this study was lower compared to most of published data. ${ }^{26}$

Previous studies in CLL reveal that ATM is a protein located in the chromosome 11q22. ATM protects the integrity of the genome by arresting cell cycle and activating DNArepair pathways. ${ }^{26,27} 11$ q22 deletions have been associated with aggressive clinical courses of the disease, ${ }^{28,16}$ a fact also observed here since this patient died of aggressive disease within 33 months.

We detected a mono-allelic deletion of $17 \mathrm{p}$ in $17.2 \%$ of patients, similar to other studies. ${ }^{29}$

p53, a transcription factor that is activated by DNA breaks, inducing cell apoptosis or cell cycle arrest. Thus p53 is critical for either the repair or death of cells with DNA damage and acts against the development of abnormal cell clones. ${ }^{30}$ In patients with CLL, the mutation of p53 gene has been detected in about $10-15 \%$ by molecular techniques. The $17 \mathrm{p} 13.1$ deletion is considered to be a marker of advanced disease and resistance to drugs. ${ }^{31}$

In the present study we found $34.5 \%$ of mono-allelic deletions for chromosome 13q14, an incidence similar to literature data (15-30\%). ${ }^{32}$ The region of 13q14.3 telomeric years) while these alterations were found in only $27.2 \%$ of elderly patients.

In an analysis of prognostic factors in CLL including the importance of the age, gender and response to treatment in survival, Catovsky et al (1989) ${ }^{33}$ suggested that age is an adverse prognostic factor. Bosch and Montserrat (2002) ${ }^{34}$ also affirmed that elderly patients have consistently shown poor prognosis, however, the reasons for these differences have not been well analyzed. Older individuals have an increased incidence of concomitant diseases. The presence of comorbidities, usually not noticed in a younger population, has a major impact on survival and on the ability to tolerate treatments. In fact, unrelated diseases are an important cause of death in older patients. Notwithstanding, the higher incidence of unfavorable cytogenetic alterations in the younger individuals observed in this study is pointing out to a valuable prognostic factor, related to the biology of the disease, and useful to predict the clinical evolution of the patient, specially among this set of population that die more frequently due to causes directly related to CLL.

In relation to gender, there was prevalence of females (70\%) in the group of unfavorable prognoses. The impact of gender on prognosis is controversial, with some studies showing no difference in survival and others demonstrating a better survival for females. The reasons for this statement are complex. Most of the explanations for a better survival rate in women with CLL is the longer life expectancy of women in the general population, as well as the fact that the disease tends to present fewer unfavorable features in women, ${ }^{34}$ an observation not confirmed in the present study.

In relation to the Binet's staging system, among the patients with worse cytogenetic prognoses, there was a 
prevalence of $\mathrm{B}$ and $\mathrm{C}$, while in the favorable group stage $\mathrm{A}$ patients prevailed, as expected. Lazaridou et al $(2000)^{25}$ demonstrated the relation between the number of abnormalities and the disease stage. Patients in stage A of Binet, had an average of less than one abnormality, those in stage $B, 1.5$ and those in stage $C$ presented 2.6 abnormalities, demonstrating the relation between complex alterations and worst prognosis.

CD38 is a transmembrane glycoprotein, present in most of T, B, natural killer, plasma cells, monocytes, macrophages and erythrocytes. Studies of the CD38 expression in CLL cells demonstrated that patients expressing this antigen in the cellular surface presented worse prognoses. ${ }^{8,35}$ We found that patients with poor prognosis cytogenetics were more frequently CD38+, as well. Abbasi et al (2003) $)^{36}$ noticed that CD38 negative patients seemed to have larger probability of presenting isolated $13 q$ deletion while Dewald et al (2003) ${ }^{37}$ demonstrated that CD38+ patients were more likely to have multiple FISH anomalies, and indicated that favorable (13q -) and unfavorable (+12,11q-,17p -) FISH anomalies can occur in stable and progressive diseases. FISH results together with CD38 expression may provide valuable prognostic information in CLL patients.

The expression of ZAP-70 (zeta-associated protein 70), a protein tyrosine kinase involved with the cellular signaling of T cells, can be evaluated through flow cytometric analysis, immunohistochemistry or immunoblot techniques, allowing the identification of worse survival when positive. ${ }^{38}$ In the group of unfavorable cytogenetics, $60 \%$ were also ZAP-70 positive. Grever et al (2003) ${ }^{39}$ demonstrated in selected high risk groups (17p-, 11q-) where progression is heterogeneous, that ZAP-70 may also distinguish patients who have a predisposition to early versus late disease progression. ZAP70 determinations in patients with CLL complement cytogenetic data and may assist in planning therapeutic decisions.

Additionally, in respect to $V_{H}$ mutation status, six of CLL patients were mutated and nine unmutated in the present study. Stilgenbauer et al (2002), ${ }^{40}$ analyzed genetic parameters in relation to prognosis and found that the overall incidence of genomic aberrations was similar in the $V_{H}$ mutated and unmutated groups. Favorable aberrations were more frequently observed in the $V_{H}$ mutated group, whereas unfavorable aberrations were overrepresented in the unmutated group.

\section{Conclusion}

We conclude that cytogenetics and FISH are important prognostic indicators and should be correlated with other prognostic parameters such as ZAP-70, CD38 and $V_{H}$ mutation status, at diagnosis, in order to predict clinical course.

\section{Resumo}

A leucemia linfocítica crônica (LLC) é o tipo de leucemia mais prevalente no Ocidente e é caracterizada por curso clínico extremamente variável. O objetivo deste estudo foi detectar as anomalias cromossômicas mais freqüentes em pacientes com $L L C$, empregando a técnica FISH, e correlacioná-las com idade, sexo, estádio clínico, expressão de CD 38 e ZAP-70. Foram encontradas alterações cromossômicas em $51,7 \%$ dos pacientes. A mais freqüente foi a del 13q14, observada em $34,5 \%$ dos casos e que esteve associada a outras anomalias em 17,2\%. Deleção $17 p 13$ foi encontrada em 17,2\% e trissomia $12 \mathrm{em} \mathrm{13,8 \%} \mathrm{(isolada} \mathrm{em}$ 6,9\% e associada à del 13q14 em 6,9\%). Deleção 11q22 foi observada em um caso em concomitância à del 13q14. Para melhor avaliar a relação entre alteração cromossômica e outros fatores prognósticos em LLC, dois grupos citogenéticos foram considerados: favorável (deleção 13q isolada e ausência de alterações) $e$ desfavorável (trissomia 12, deleção 17p13, deleção 11q22 e duas anomalias simultâneas). As alterações desfavoráveis foram mais freqüentemente observadas em indivíduos jovens ( $<60$ anos) e em mulheres $(70 \%)(p=0,04)$. Em relação ao sistema de estadiamento de Binet, houve tendência dos pacientes com alterações cromossômicas desfavoráveis apresenteram-se nos estágios $B$ e $C$ enquanto no grupo favorável prevaleceram aqueles com estágio A. Em adição, pacientes com achados citogenéticos de prognóstico desfavorável tiveram tendência a expressar proteínas CD 38 e ZAP-70.Rev. bras. hematol. hemoter. 2006;28(1):5-10.

Palavras-chave: Leucemia linfocítica crônica; (FISH); citogenética.

\section{References}

1. Catovsky D, Fooks J, Richards S. Prognostic factors in chronic lymphocytic leukaemia: the importance of age, sex and response to treatment in survival. British Journal of Haematology 1989;72:141-149.

2. Dighiero G, Maloum K, Desablens B et al. Chlorambucil in indolent chronic lymphocytic leukemia: French Cooperative Group on Chronic Lymphocytic Leukemia. New England Journal of Medicine 1998;338: 1.506-1.514.

3. Rozman C, Montserrat E. Current concepts: chronic lymphocytic leukemia. New England Journal of Medicine 1995; 333:1.052-1.057.

4. Döhner H, Stilgenbauer S, Benner A et al. Genomic aberrations and survival in chronic lymphocytic leukemia. New England Journal of Medicine 2000; 343:1.910-1.916.

5. Zwiebel JA, Cheson BD. Chronic lymphocytic leukemia: Staging and prognostic factors. Seminars in Oncology 1998;25:42-59.

6. Rai KR, Sawitsky A, Cronkite EP et al. Clinical staging of chronic lymphocytic leukemia. Blood 1975;46:219-234.

7. Binet JL, Auquier A, Dighiero G et al. A new prognostic classification of chronic lymphocytic leukemia derived from a multivariate survival analysis. Cancer 1981;48:198-206.

8. Damle RN, Wasil T, Fais F et al. IgV gene status and CD38 expression as novel prognostic indicators in chronic lymphocytic leukemia. Blood 1999; 94:1.840-1.847.

9. Ibrahim S, Keating M, Do KA et al. CD38 expression as an important prognostic factor in B-cell chronic lymphocytic leukemia. Blood 2001; 98:181-186.

10. Hamblin TJ, Orchard JA, Ibbotson RE et al. CD38 expressions and immunoglobulin variable region mutations are independent prognostic 
variables in chronic lymphocytic leukemia, but CD38 expression may vary during the course of the disease. Blood 2002; 99:1.023-1.029.

11. Bosch F, Crespo M, Villamor N et al. ZAP-70 expression has a prominent position among prognostic factors in chronic lymphocytic leukemia (CLL): Results of a multivariate analysis in 192 patients. Blood 2003 (abstr.) 102 (S):665.

12. Wiestner A, Rosenwald A, Barry T et al. ZAP70 expression identifies BCLL with unmutated immunoglobulin genes, worse clinical outcome and a distinct gene expression profile. Blood 2002 (abstr.) 100 (S):168.

13. Orchard JA, Ibbotson RE, Davis ZA et al. ZAP-70 evaluation by flow cytometry is a significant prognostic marker in B-CLL. Blood 2002 (abstr.) 100 (S):168.

14. Vasconcelos Y, Oppezzo P, Vuillier F et al. Combination of LPL/ADAM29 ratio and ZAP-70 expression can dispense $\mathrm{IgV}_{\mathrm{H}}$ sequencing in CLL. Blood 2003 (abstr.) 102 (S):346.

15. Juliusson G, Merup M. Cytogenetics in chronic lymphocytic leukemia. Seminars in Oncology 1998;25:19-26.

16. Stilgenbauer S, Döhner H, Lichter P. Genomic aberrations in B-cell chronic lymphocytic leukemia. In: Cheson BD. Chronic lymphoid leukemias, $2^{\text {nd }}$ ed. Marcel Dekker Inc 2001. New York, 353-376.

17. Mould S, Gardiner A, Corcoran M et al. Trisomy 12 and structural abnormalities of 13q14 occurring in the same clone in chronic lymphocytic leukemia. British Journal of Haematology 1996;92:389-392.

18. Hjalmar V, Hast R, Kimby E. Sequential fluorescence in situ hybridization analyses for trisomy 12 in chronic leukemic B-cell disorders. Haematologica 2001;86:174-180.

19. Matutes E, Oscier D, Garcia-Marco J et al. Trisomy 12 defines a group of CLL with atypical morphology: correlation between cytogenetic, clinical and laboratory features in 544 patients. British Journal of Haematology 1996; 92:382-388.

20. Rai KR, Döhner H, Keating MJ et al. Chronic lymphocytic leukemia: Case-Based Session. Hematology 2001;140-156.

21. Amiel A, Arbov L, Manor Y, et al. Monoallelic p53 deletion in chronic lymphocytic leukemia detected by interphase cytogenetics. Cancer Genetics and Cytogenetics 1997; 97:97-100.

22. Hallek M, Hallek KI, Emmerich B. Prognostic factors in chronic lymphocytic leukemia. Leukemia 1997;2 (11 suppl):4-13.

23. Chauffaille MLLF, Vieira S, Martins SLR. Importância do cariótipo em leucemia linfocítica crônica: relato de 18 casos. Jornal Brasileiro de Patologia e Medicina Laboratorial 2004;40:75-78.

24. Que TH, Garcia-Marco J, Ellis J et al. Trisomy 12 in chronic lymphocytic leukemia detected by FISH: Analysis by stage, immunophenotype, and morphology. Blood 1993;82:571-575.

25. Lazaridou A, Miraxtsi C, Korantzis J et al. Simultaneous detection of BCL-2 protein, trisomy 12, retinoblastoma and p53 monoallelic gene delections in B-cell chronic lymphocytic leukemia by FISH: Relation to disease status. Leukemia and Lymphoma 2000;36:503-512.

26. Eclache V, Caulet-Maugendre S, Poirel HA et al. Cryptic deletion involving the ATM locus at 11q22.3 q23.1 in B-cell chronic leukemia and related disorders. Cancer Genetics and Cytogenetics 2004;152:72-76.

27. Starostik P, Manshouri T, O'Brian S et al. Deficiency of the ATM protein expression defines an aggressive subgroup of B-Cell chronic lymphocytic leukemia. Cancer Research 1998;58:4.552-4.557.

28. Neilson JR, Auer R, White D et al. Deletions at 11q identify a subset of patients with typical CLL who show consistent disease progression and reduced survival. Leukemia 1997;11:1.929-1.932.

29. Döhner H, Stilgenbauer S, Döhner K et al. Chromosome aberrations in Bcell chronic leukemia: reassessment based on molecular cytogenetic analysis. Journal of Molecular Medicine 1999;77:266-281.

30. Giles FJ, Bekele BN, O'Brien S et al. A prognostic model for survival in chronic lymphocytic leukaemia based on p53 expression. British Journal of Haematology 2003;121:578-585.
31. Callet-Bauchu E, Salles G, Gazzo S et al. Translocations involving the short arm of chromosome 17 in chronic B-lymphoid disorders: frequent occurrence of dicentric rearrangements and possible association with adverse outcome. Leukemia 1999;13:460-468.

32. Garcia-Marco JA, Price CM, Catovsky D. Interphase cytogenetics in chronic lymphocytic leukemia. Cancer Genetics and Cytogenetics 1997; 94:52-58.

33. Catovsky D, Fooks J, Richards S. Prognostic factors in chronic lymphocytic leukaemia: the importance of age, sex and response to treatment in survival. British Journal of Haematology 1989;72:141-149.

34. Bosch F, Montserrat E. Refining prognostic factors in chronic lymphocytic leukemia. Reviews in Clinical and Experimental Hematology 2002;6: 335-349.

35. Del Poeta G, Maurillo L, Venditti A et al. Clinical significance of CD38 expression in chronic lymphocytic leukemia. Blood 2001;98:2.633-2.639.

36. Abbasi SY, Mavromatis BH, Ozdemirli M et al. Correlation of CD38 expression and cytogenetic abnormalities in chronic lymphocytic leukemia (CLL). Blood 2003 (abstr.);102 (S): 350.

37. Dewald GW, Brockman SR, Paternoster SF et al. Chromosome anomalies detected by interphase fluorescence in situ hybridization: correlation with significant biological features of B-cell chronic lymphocytic leukemia. British Journal of Haematology 2003;121:287-95.

38. Pittner BT, Tschumper RC, Kimlinger TK et al. Expression of ZAP-70 in both unmutated and mutated leukemic CLL B cells indicates lack of efficacy as a surrogate marker for immunoglobulin mutational status. Blood 2003 (abstr.);102 (S):34.

39. Grever MR, Dewald GW, Lucas DM et al. ZAP-70 protein expression varies by interphase cytogenetic group and may predict disease progression to requirement of treatment among select genetic groups in patients with chronic lymphocytic leukemia (CLL). Blood 2003 (abstr.);102 (S):73

40. Stilgenbauer S, Bullinger L, Lichter P et al. Genetics of chronic lymphocytic leukemia: genomic aberrations and $\mathrm{V}_{\mathrm{H}}$ gene mutation status in pathogenesis and clinical course. Leukemia 2002;16:993-1.007.

Avaliação: Editor e dois revisores externos.

Conflito de interesse: não declarado

Recebido: 13/10/2005

Aceito após modificações: 20/02/2006

Recursos financeiros: Research supported by Fapesp proc.no. 01/14242-9 and proc.no 01/13086-3 